\title{
Innovative Entrepreneurship in Countries of Eastern Europe
}

Submitted 30/05/20, $1^{\text {st }}$ revision 12/06/20, $2^{\text {nd }}$ revision 14/07/20, accepted $30 / 07 / 20$

\author{
Iaroslav V. Petrunenko ${ }^{1}$, Mariia F. Plotnikova ${ }^{2}$, Alona V. Nieliepova ${ }^{3}$, \\ Tamila Yu. Bilousko ${ }^{4}$, Anastasiia V. Mazur ${ }^{5}$, Iryna M. Goncharenko ${ }^{6}$
}

\begin{abstract}
:
Purpose: Ensuring stable economic growth globally is impossible without the use of modern technologies in the economic development of the nations. After all, every year innovations penetrate more and more into all spheres of state and the society, which further identifies them as a key factor in international competition. Consequently, the need arises to develop innovative entrepreneurship within the country on the way to ensuring cross-border innovative cooperation. Therefore, the main purpose of this study is to determine the peculiarities of the development of innovative enterprise in Eastern Europe.

Design/Methodology/Approach: This research is based on the statistical information provided on the official sites of statistical information, namely, the World Intellectual Property Organization, Organization for Economic Cooperation and Development, The Global Entrepreneurship and Development Institute on the development of innovative entrepreneurship for the countries of Eastern Europe in recent years.

Findings: The results show that innovative entrepreneurship has an extremely large and new potential in Eastern Europe, which at the time of the study due to the peculiarities of historical and cultural development, is undiscovered. It creates a large gap in the pace of innovative entrepreneurship in these countries compared to other parts of Europe.

Practical Implications: The study raises awareness of the pace of development of the digital economy and innovative entrepreneurship in Eastern Europe, practical mechanisms for the formation of innovative entrepreneurship, as well as further ways to stimulate its development. Originality/Value: The study emphasizes that the existing and new potential for innovative entrepreneurship is one of the driving forces of economic development in Eastern Europe, which will balance the existing disparities compared to other countries in the European region with the right incentives from government agencies and international institutions.
\end{abstract}

${ }^{1}$ Associate Professor, National University “Odesa Law Academy”, Odesa, 65009, Ukraine, E-mail: petrunenko@email.ua

${ }^{2}$ Associate Professor, Zhytomyr National Agroecological University, Zhytomyr, 10008, Ukraine, E-mail: mfplotnikova@gmail.com

${ }^{3}$ Associate Professor, National University of Life and Environmental Sciences of Ukraine, Kyiv, 03041, Ukraine, E-mail: a.v.nelepova@gmail.com

${ }^{4}$ Associate Professor, Kharkiv National Agrarian University named after V. V. Dokuchaiev,

Dokuchaevske - 2, 62483, Ukraine, E-mail: tbilousko@ukr.net

${ }^{5}$ Postgraduate student, Ivan Franko National University of Lviv, Lviv, 79000, Ukraine,

E-mail: anastasiia.mazur@lnu.edu.ua

${ }^{6}$ Associate Professor, Kyiv National University of Technologies and Design, Kyiv, 01011,

Ukraine,E-mail: ig75dv@gmail.com 
Keywords: Innovations, innovative entrepreneurship, mechanism, components of innovative entrepreneurship, entrepreneurship development index, digital entrepreneurship development index, gross expenditures and development costs, patent applications.

JEL Classification: $H 4 ; H 44, L 1, L 3, L 5$.

Paper Type: Research article.

\section{Introduction}

Innovative processes in modern economic life are given an extremely important role and the identification and consideration of the features of their implementation are a prerequisite for the effective implementation of the economic strategy of the state. Only when following this path, the country's economy can take a worthy place in the global business environment. Herewith, the creation of effective incentives for the promotion of innovative models of business representatives' economic behavior is one of the significant tasks in the development and implementation of economic policy of the state.

Along with this, objective changes in economic life have provoked the emergence of a new model of economic development, which is characterized by completely deformed features and priorities. An important role in the social life of the new generation is played by industries, the development of which is ensured by modern technologies, as well as those industries that are directly involved in meeting the needs of consumers. According to world experience, the greatest result from the introduction of innovations is achieved in the sphere of industry. Production is reoriented from mass consumption to individual needs, represented in markets of small capacity. The number of small and medium-sized entrepreneurship with the ability to adapt quickly to changing environmental conditions is growing rapidly.

The spread of the rush modernization of life, in turn, causes an increase in requirements for the quality of the final products of manufacturers, presented either in the form of goods or services, as well as their range. The society naturally responds to these processes by making them more open and receptive to innovative phenomena, as a basis for achieving the necessary state to fully meet the new needs of consumers. Based on the foregoing, it can be argued that the investigation of innovative entrepreneurship's development in modern conditions is extremely relevant, especially through the prism of its spreading in the countries of Eastern Europe, which are at the stage of development of innovative economy. 


\section{Literature Review}

Processing the available literature on the development of innovative entrepreneurship in different countries makes it possible to draw conclusions on the increasing attention on the part of scientists to this issue since the beginning of the XXIst century.

In particular, at the end of the last century, Wennekers and Thurik (1999) recognized entrepreneurship as a micro-engine of innovation and economic growth. In addition, Grilo and Thurik (2006) argue that entrepreneurial activity is the basis for innovation, productivity growth, competitiveness, and job growth.

Dahlstrand and Stevenson (2008) in their study show that entrepreneurship remains a key element in ensuring dynamic development, innovation, and flexibility in countries with a high level of economic development, as well as in those states, where the economy is being developed. Confirmation of this fact is the thesis presented on the official website of The World Bank (2019): "Innovation and entrepreneurship are recognized as key components of a competitive and dynamic economy”.

On the website of The Innovation Police Platform (n.d.), it has been noted that in the context of overcoming economic and financial crises, special attention is given to the innovative enterprise, as one of the basic directions of promoting economic growth, creating new jobs and reducing poverty, and therefore its development can help in solving key social issues.

A general definition of the term "innovative entrepreneurship" is obtained from the study of Golubev (2014), where the author means a social-technical economic process that leads to the creation of better goods, services and technologies with improved properties through the use of innovation.

The Global Entrepreneurship Monitoring (GEM) Report for 2019 states that most scholars and politicians agree that entrepreneurship is a critical element in ensuring the development and well-being of the society. Thus, entrepreneurs create new jobs, while contributing to the spread of innovation, accelerating structural changes in the economy. In addition, they indirectly increase productivity by introducing a new kind of competition. Thus, entrepreneurship acts as a kind of catalyst for economic growth and national competitiveness (Bosma et al., 2020).

At the same time, Prokopowicz (2018) emphasizes that entrepreneurship should be supported by the state through investment funds that participate in the financing of innovative start-up companies. The state should take measures to stimulate the development of entrepreneurship and innovation through central bodies, as well as local governments, especially in the conditions of modern development of the economy based on knowledge (Prokopowicz, 2018). In addition, Shvets et al. (2013), note that the lack of advanced investment technology, which requires the use of tools 
for market's analysis and forecasting of specific goods, the inability to calculate financial aspects and create financing schemes significantly slows down management decision-making processes (Shvets et al., 2013), and thus constrains the development of innovations.

Kubiv et al. (2020), while investigating the innovative potential of European countries, have noted that there is a significant gap between the countries of Eastern Europe in terms of innovative potential, caused by the prerequisites for its development, which in its turn forms a requirement for further study of the development of innovative entrepreneurship in these countries.

\section{Research Methodology}

The works of foreign and domestic researchers, official statistics, and reports constitute the methodological basis of the study; on their basis the conclusions are formed on the state of development of entrepreneurship in the countries of Eastern Europe.

Methods of analysis, synthesis, formalization, logical abstraction, theoretical knowledge, monographic, systematization and classification, abstract-logical methods and others have been used. Data from the World Intellectual Property Organization, Organization for Economic Cooperation and Development, The Global Entrepreneurship and Development Institute have been used to assess the level of development of innovative entrepreneurship in the countries of Eastern Europe.

\section{Empirical Findings}

The experience of functioning countries with advanced economies shows that the most developed countries are those with a high level of entrepreneurial activity and innovation. Although achieving a minimum level of development further stimulates the development of these two components, through the creation of basic access to capital and institutional stability. Thus, the impact of innovation and entrepreneurship on the economy and the society cannot be overestimated. In fact, this influence goes beyond the usual growth of labor productivity, competitiveness, and job creation, and extends to the framework of infrastructure, environment, and social inclusion (Averburg, 2020).

In particular, the influence of the development of innovative entrepreneurship on the country of its spreading can be depicted as shown in Figure 1.

The experience of expanding Celtel's telecommunications network in Africa at the beginning of this century is a vivid example of the positive impact of innovative entrepreneurship when the lack of coverage in some countries has hindered the development of the company. In order to solve this problem, Celtel's representatives 
decided to expand the network of cell towers at their own expense, as well as to build additional infrastructure, including roads, so that to provide the access of technicians to these towers in addition to water supply, as well as to ensure basic access to water in remote areas for workers. This investment has led to significant business growth for companies, as well as caused a significant step towards improving infrastructure in the countries where this process took place.

Figure 1. Directions of positive influence of innovative entrepreneurship on the functioning of the world countries

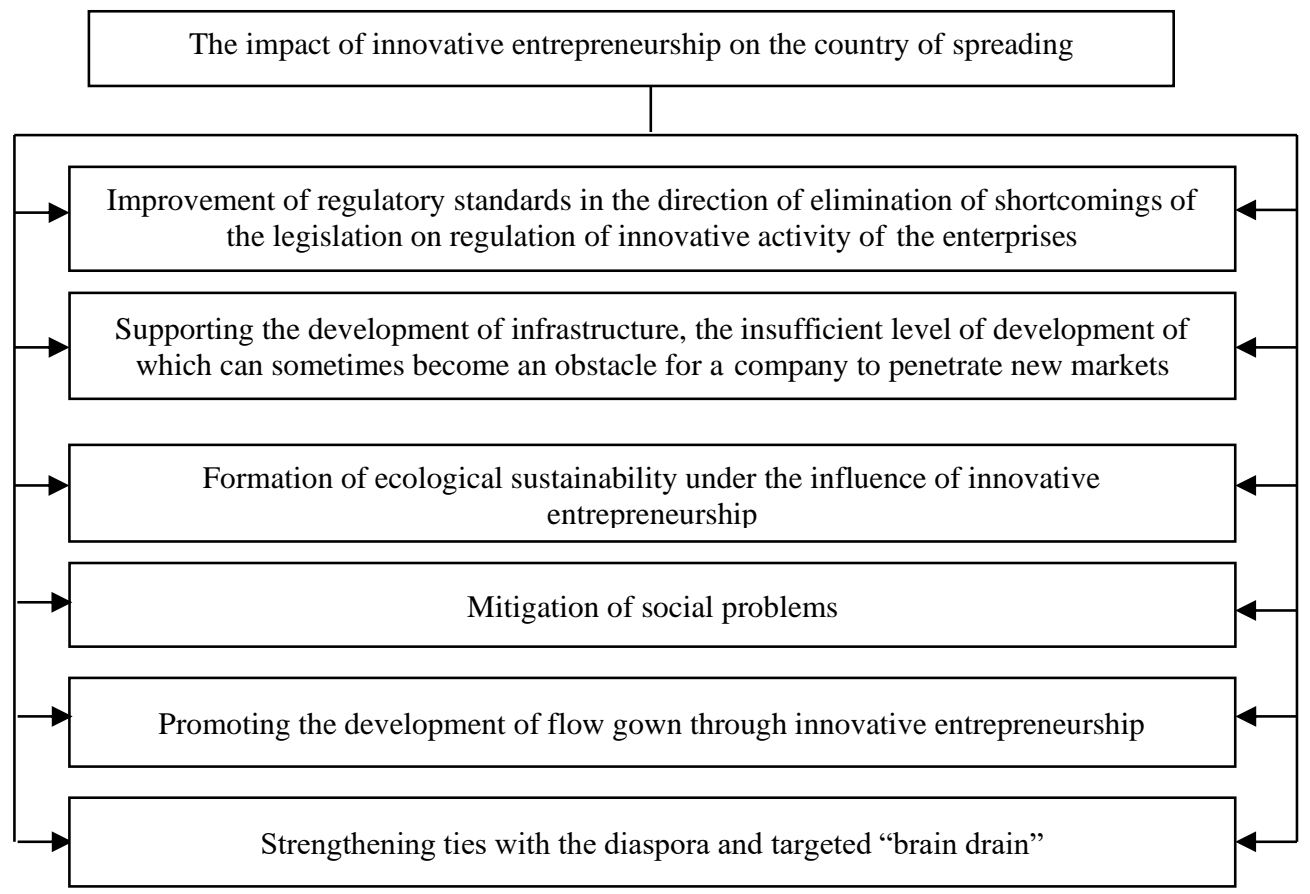

Source: Averburg (2020).

Innovative entrepreneurship can take various forms; the key ones are distinguished among the various forms as shown in Figure 2.

In general, the development of innovative entrepreneurship is a complex mechanism consisting of several elements. Visual display of this mechanism is reflected in Figure 3.

Thus, according to the data shown in the figure, the mechanism of formation of innovative development of entrepreneurship consists of resource support of innovative development, external and internal factors, principles, objectives of innovative development, its efficiency, development management functions, its assessment and approximate control. 
Figure 2. Key forms of development of innovative entrepreneurship

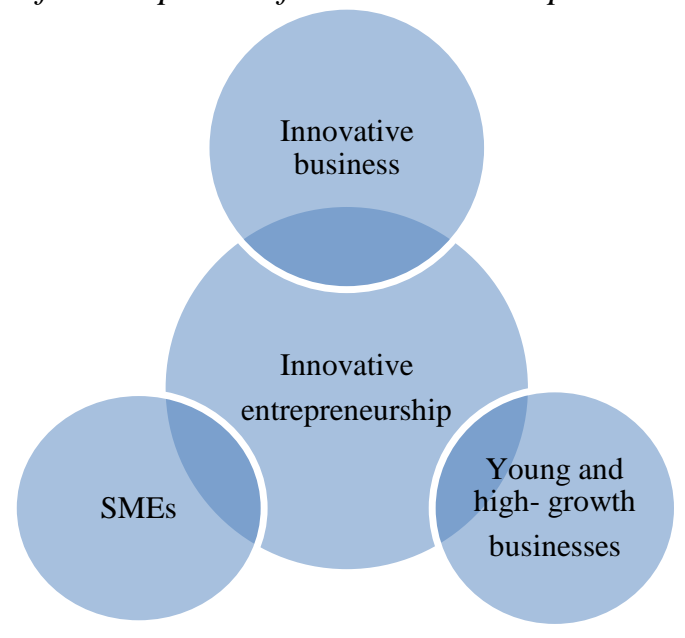

Source: OECD (2010).

Figure 3. The mechanism of formation of innovative entrepreneurship

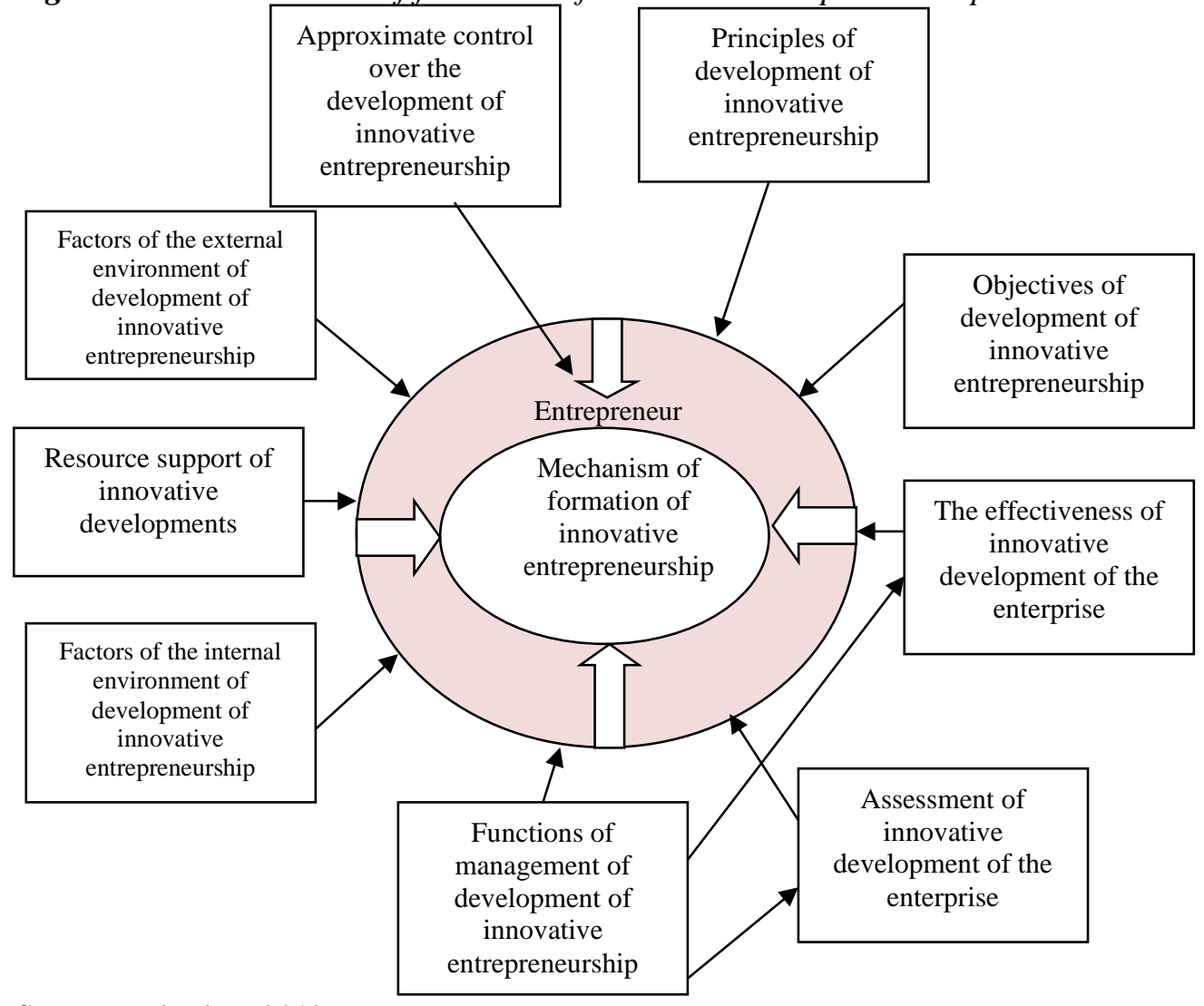

Source: Zabashta (2019). 
In addition, there are different models of innovative entrepreneurship. The following ones are distinguished among them, namely (Uvarova et al., 2010):

1. Model of active spreading of innovations, through ensuring interaction between the government, scientific institutions, enterprises, and higher educational institutions to organize the implementation of innovations.

2. Model of state support of national innovation structures to ensure rapid access of goods to the international markets.

3. Model of local innovation environment being implemented by creating technoparks, technopolises, clusters, etc.

4. CIS model, which is based on cooperation of science and technology between CIS enterprises through the implementation of joint programs, orders, etc.

5. The formation of intersectoral scientific and technical complexes; it is like the model number 3 above and involves the use of the same levers and tools.

6. Model of world cooperation through active participation of the state in scientific and technical cooperation, and an exchange of results of scientific and technical activities.

According to the results of the analysis of statistical information presented on the websites of the World Intellectual Property Organization (n.d.), Organization for Economic Cooperation and Development, The Global Entrepreneurship and Development Institute, the development of innovative entrepreneurship has been gaining momentum over the last decade. Moreover, the direct dependence between the level of economic development and the level of spreading innovative entrepreneurship is monitored. For the purposes of our investigation, we will analyze the level of development of innovative entrepreneurship in the countries of Eastern Europe, including, Moldova, Romania, Hungary, Poland, the Czech Republic, Slovakia, Ukraine, and Bulgaria.

Let us start the analysis by determining the general Index of Entrepreneurship Development in these countries in 2018-2019 (Figure 4):

Thus, according to the data shown in Figure 4, we can see the controversial dynamics of change in the Entrepreneurship Development Index. Thus, the value of the abovementioned index has decreased in countries such as, Ukraine, Slovakia, Poland, and Moldova. Growth is observed in such countries as, Bulgaria, the Czech Republic, Hungary, and Romania. However, despite the decrease in the Entrepreneurship Development Index, such country as Poland has improved its position in the ranking by 1 position and moved from the 30 th place to the 29 th place.

The study of the Digital Entrepreneurship Index in these countries based on data for 2019 was conducted to comprehensively study the situation (Table 1). 
Figure 4. Entrepreneurship Development Index for 2018-2019

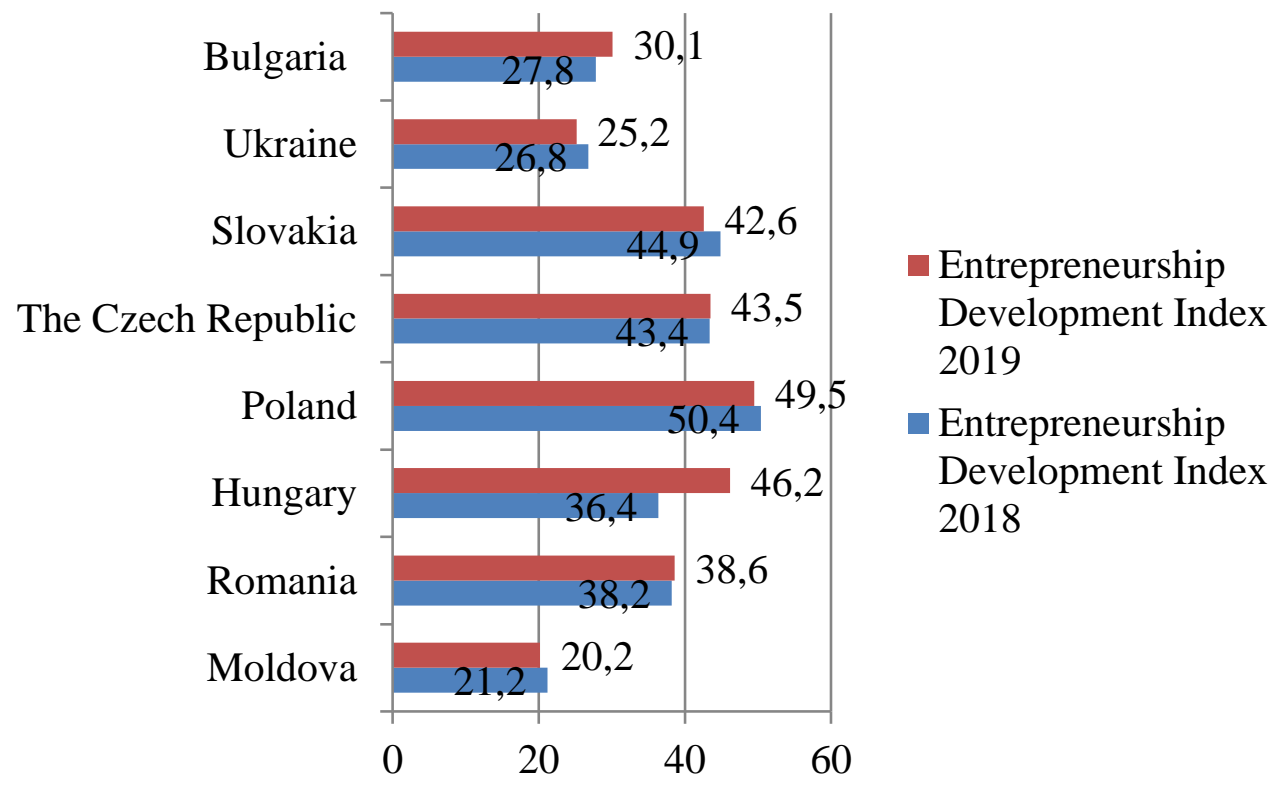

Source: Acs et al. (2020).

Table 1. The Digital Entrepreneurship Index (DEI) ranking of the East Europe countries, 2019

\begin{tabular}{|l|l|l|l|}
\hline Rank & Country & DEI 2019 & GDP 2017 \\
\hline $\mathbf{2 8}$ & The CzechRepublic & 48.9 & 31339 \\
\hline $\mathbf{3 8}$ & Poland & 40.5 & 26036 \\
\hline $\mathbf{3 9}$ & Slovakia & 40.4 & 29212 \\
\hline $\mathbf{4 1}$ & Hungary & 38.3 & 25664 \\
\hline $\mathbf{4 4}$ & Bulgaria & 35.0 & 17795 \\
\hline $\mathbf{4 7}$ & Romania & 32.9 & 21615 \\
\hline $\mathbf{5 4}$ & Ukraine & 29.2 & 7668 \\
\hline $\mathbf{7 0}$ & Moldova & 24.3 & 4944 \\
\hline
\end{tabular}

Source: Acs et al. (2020).

Thus, according to data presented in Table 1, the highest indicator of the Digital Entrepreneurship Index has been recorded for the Czech Republic at the level 48.9. It is followed by Poland and Slovakia, where the values of this index are 40.5 and 40.4, respectively. The lowest level of DEI, among the countries of Eastern Europe, has been revealed in Ukraine and Moldova, where the values were 29.2 and 24.3, respectively. This goes to prove that the development of innovative entrepreneurship in these countries is at a low level. 
In addition, along with the data on the value of the Digital Entrepreneurship Index, Table 1 provides information on the position of each country in the overall ranking of countries. Thus, the Czech Republic, where DEI is the highest among the countries of Eastern Europe, occupies the 28th position, while Poland is on the 38th place, and Ukraine and Moldova are on the 54th and the 70th places, respectively. Based on the foregoing, it can be argued that innovative entrepreneurship in this part of Europe is carried out at a slightly lower pace to compare with others.

Along with this, the Organization for Economic Cooperation and Development data on gross domestic costs (expenditures) for research and digital technologies testify to the degree of development of an innovative enterprise. Let us analyze the dynamics of changes in expenditures in the countries of Eastern Europe, drawing up the results in Table 2.

Table 2. Gross Domestic Expenditures on Research and Digital (R\&D) in 2013-2018

\begin{tabular}{|l|l|l|l|l|l|l|}
\hline Country & $\mathbf{2 0 1 3}$ & $\mathbf{2 0 1 4}$ & $\mathbf{2 0 1 5}$ & $\mathbf{2 0 1 6}$ & $\mathbf{2 0 1 7}$ & $\mathbf{2 0 1 8}$ \\
\hline $\begin{array}{l}\text { The Czech } \\
\text { Republic }\end{array}$ & 1.900 & 1.973 & 1.929 & 1.680 & 1.791 & 1.930 \\
\hline Slovakia & 0.822 & 0.878 & 1.163 & 0.791 & 0.886 & 0.837 \\
\hline Poland & 0.871 & 0.940 & 1.003 & 0.964 & 1.034 & 1.213 \\
\hline Romania & 0.388 & 0.382 & 0.488 & 0.480 & 0.503 & 0.505 \\
\hline Hungary & 1.387 & 1.349 & 1.347 & 1.190 & 1.332 & 1.533 \\
\hline
\end{tabular}

Source: OECD (2020).

Analyzing the data presented in Table 2, we can conclude that the amount of expenditures in different countries on research and digital technologies during the study period had controversial trends. In the Czech Republic, expenditures in this area increased until 2015, then decreased in 2016 and only in 2018 reached a previous maximum. A somewhat similar trend was also relevant in Slovakia, but at the end of 2018 the amount of gross expenditures on research and digital technologies remained at the level of 2014 .

If we analyze the experience of Poland and Hungary, we can observe that the decrease in expenditures took place only in 2016, and throughout the rest of the study period there has been a gradual increase.

There has been a steady upward trend in R\&D expenditures in Romania, but their total amount has remained small compared to other countries. Summing up, it should be noted that the top three countries in terms of gross spending on research and digital technology are as follows: the Czech Republic, Poland, and Hungary.

In addition, the development of innovative entrepreneurship in the country is evidenced by the number of patent applications. Consequently, let us analyze the number of applications submitted in the countries of Eastern Europe in 2018, drawing up the results by using Figure 5 . 
Figure 5. Number of patent applications in the countries of Eastern Europe in 2018

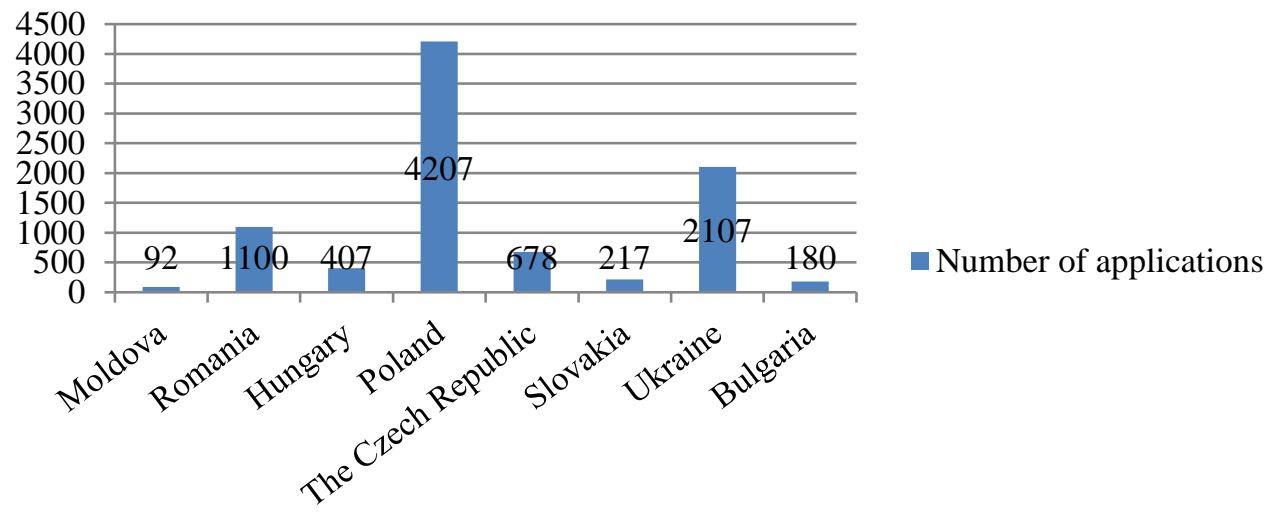

Source: World Intellectual Property Organization (n.d.)

Thus, studying the presented Figure 5, we can note that the largest number of patent applications has been registered in Poland, Ukraine and Romania, and the smallest number is observed in Moldova, Bulgaria, and Slovakia. Such trend indicates the intensification of innovation in the countries with the largest number of applications. At the same time, the described dynamics indicates decrease of this activity in Moldova, Bulgaria, and Slovakia, which is a negative factor.

One of the reasons for arising the situation with the slow development of innovative entrepreneurship in some Eastern European countries, especially in post-Soviet countries such as Ukraine and Moldova is the dominance in the economic environment of large enterprises involved in old industries that have provided economic development since their independence, as well as the actual lack of innovative enterprises.

According to the results of the study, in modern conditions, the innovative potential of Eastern European countries is used insignificantly, which has been caused by low financing of investment projects, lack of proper legislative conditions for the protection of intellectual property, lack of financial resources for enterprises to acquire international patents, along with neglect of marketing research in the modern technological market.

In addition, there is a problem of underdeveloped innovation infrastructure, as well as its low quality, which ultimately affects the occurrence of inflated transaction costs for the search for information on innovation development and the search for partners. Such situation forms a kind of chain reaction, generating an increase in interregional disparities in the location of innovation infrastructure, which in turn reduces the prestige of intellectual activities because of too much time spent on research and lack of sufficient material incentives. 
However, along with a decrease in the activity of innovative enterprises, the positive dynamics connected with the large number of applications filed for patents in some countries of Eastern Europe is also observed, indicating the unused intellectual potential of these countries, which in the future may become an impetus for the development of innovative entrepreneurship.

To improve the current situation, it is also important to take into account the experience of advanced countries concerning the issue of various structures' formation to support innovative entrepreneurship; they have been already created in Poland, the Czech Republic and Slovakia, which raised the country to the top of the ranking among European countries.

In addition, an important role in this process is also assigned to the state, which should generate a system of rules for the activities of innovation market participants, as well as monitor their compliance through the formation of a favorable institutional environment and institutional infrastructure.

The study and adaptation of international experience concerning the development of innovative entrepreneurship in the context of limited financial resources and in the presence of significant scientific and technical potential will also be an important step towards the development of innovative entrepreneurship in the countries of Eastern Europe. After all, the development of innovative entrepreneurship in each of the countries has faced certain difficulties. Therefore, it is important to find similar preconditions for its development and implement them in the activities of a country.

\section{Discussion and Conclusions}

Based on the study conducted, it has been established that innovative entrepreneurship is the key to successful economic development of the country, ensuring a high level of employment, increasing productivity, infrastructure development and maintaining social stability. At the same time, within the framework of this scientific investigation, we have determined the possible directions of the positive impact of the innovative entrepreneurship on the country of its distribution, in particular, by the example of the development of infrastructure in Africa by Celtel, which, due to an attempt to expand the telecommunication network, indirectly provoked the development of transport communication and also water supply.

However, considering the historical past of countries' functioning, the development of innovative entrepreneurship in their working platforms is carried out at different rates. This is especially noticeable in Eastern European countries, some of which belong to post-socialist countries, Ukraine, and Moldova, in particular. In turn, countries that have been connected with the European community for a long time show a much higher rate of development of entrepreneurship and innovation. The results of the activities of Poland, the Czech Republic and Slovakia are the striking example; 
they occupy the first lines in the ratings of the Digital Entrepreneurship Index and the expenditures for research and digital technologies.

The lag of other countries is explained by ineffective state policy in the field of innovation, lack of legal protection of intellectual property and low development of innovation infrastructure, which forms a field for further work of both public authorities and private entities to improve the situation, especially taking into account the potential identified in the investigation for the development of innovative entrepreneurship in the countries of Eastern Europe, which currently lag far behind its neighbors.

So, the investigation conducted contains information about the essence of innovative entrepreneurship, as well as areas of its positive impact on the performance of both the country as a whole and business entities in it. Thus, the positive impact includes stimulating the improvement of the legal framework, internal infrastructure, the formation of environmental sustainability, mitigation social problems, etc. In addition, the study has identified the basic forms of innovative entrepreneurship, as well as the mechanism of its implementation.

The criterion for determining the level of development of innovative entrepreneurship in the country is the Digital Entrepreneurship Index, the results of which for Eastern European countries show that the highest Digital Entrepreneurship Index is recorded for the Czech Republic with the value 48.9. It is followed by Poland and Slovakia, where the values of this index are 40.5 and 40.4, respectively. The lowest level of DEI, among the countries of Eastern Europe, has been revealed in Ukraine and Moldova, where the values were 29.2 and 24.3 , respectively. Such results go to prove that the development of innovative entrepreneurship in these countries is at slow level.

In addition, the development of innovative entrepreneurship is evidenced by the gross costs for research and digital technologies, which have been analyzed during the study. Therefore, the largest expenditures in this area are revealed in the Czech Republic, Slovakia and Poland, and the lowest ones are observed in Romania and Hungary. Such countries as Ukraine, Moldova and Bulgaria are not included in the ranking.

On the other hand, the determination of the number of registered patents in the countries of Eastern Europe indicates the unexercised potential for the development of innovative entrepreneurship in countries, lagging in terms of its development. Along with this, the unevenness of the indicators of innovative entrepreneurship's development in the countries of Eastern Europe is explained by a few factors, namely:

$>$ the historical prerequisites for the functioning of countries,

$>$ the lack of an adequate legislative framework,

$>$ the lack of a procedure for state support of innovation projects,

$>$ low level of development of innovation infrastructure, 
low spreading of the practice of marketing research of the technology market, etc.

However, the unexercised development potential of an innovative entrepreneurship established during the investigation gives hope for improving the position of Eastern European countries in the overall ranking of the level of innovative entrepreneurship as soon as possible.

\section{References:}

Acs, Z.J., Szerb, L., Komlósi, É., Lafuente, E., Song, A.K. 2020. Measuring digital entrepreneurship ecosystems: The Digital Entrepreneurship Index. Available at: https://thegedi.org/wpcontent/uploads/2020/04/Digital_Entrepreneurship_Index_report_v0.pdf.

Averburg, A. 2020. 6 Ways Innovation and Entrepreneurship Promote Prosperity. Digital @ Dai. Available at: https://dai-global-digital.com/6-ways-innovation-andentrepreneurship-promote-prosperity.html.

Bosma, N., Hill, S., Ionescu-Somers, A., Kelley, D., Levie, J., Tarnawa, A. 2020. Global Entrepreneurship Monitor: 2019/2020 Global Report. The Global Entrepreneurship Research Association. Available at: https://www.gemconsortium.org/report/gem2019-2020-global-report.

Dahlstrand, A., Stevenson, L. 2010. Innovative Entrepreneurship Policy: Linking Innovation and Entrepreneurship in a European Context. Annals of Innovation \& Entrepreneurship, 1(1). https://doi.org/10.3402/aie.v1i1.5845.

Golubev, A.A. 2014. Economics and innovation management: a training manual. SPbSU ITMO, St. Peterburg, Russia.

Grilo, I., Thurik, R. 2006. Latent and Actual Entrepreneurship in Europe and the US: Some Recent Developments. SCALES-paper N200514. EIM Business and Policy Research. Available at: https://ideas.repec.org/p/eim/papers/n200514.html.

Kubiv, S., Bobro, N., Lopushnyak, G., Lenher, Y., Kozhyna, A. 2020. Innovative potential in European countries: Analytical and legal aspects. International Journal of Economics and Business Administration, 8(2), 250-251.

OECD. 2010. SMEs, Entrepreneurship and Innovation, OECD Studies on SMEs and Entrepreneurship. http://dx.doi.org/10.1787/9789264080355-en.

OECD. 2020. Gross Domestic Spending on R\&D (indicator). Available at: https://data.oecd.org/rd/gross-domestic-spending-on-r-d.htm.

Prokopowicz, D. 2018. Should the state support the development of entrepreneurship and innovation? Available at:

https://www.researchgate.net/post/Should_the_state_support_the_development_of_en trepreneurship_and_innovation.

Shvets, V., Rozdobudko, E., Solomina, G. 2013. Aggregated methodology of multicriteria economic and ecological examination of the ecologically oriented investment projects. Scientific bulletin of National Mining University, 3, 139-144.

The Innovation Police Platform. n.d. Innovative entrepreneurship. Available at: http://www.innovationpolicyplatform.org/www.innovationpolicyplatform.org/content /innovative-entrepreneurship/index.html. 
The World Bank. 2019. Innovation \& Entrepreneurship: Innovation and entrepreneurship are recognized as key building blocks of competitive and dynamic economies. Available at: https://www.worldbank.org/en/topic/innovation-entrepreneurship.

Uvarova, Iu., Hnylobokov, I., Boiakova, N. 2010. Improvement of the management of the innovation process of the enterprise. Ekonomika pidpryiemstva, 4, 30-34.

Wennekers, S., Thurik, R. 1999. Linking entrepreneurship and economic growth. Small Business Economics, 13, 27-55.

World Intellectual Property Organization. n.d. Available at: https://www.wipo.int/portal/en/index.html.

Zabashta, E. 2019. Theoretical Fundamentals of Formation of Innovative Development of Entrepreneurship. Baltic Journal of Economic Studies, 5, 100-101. 